\title{
CXXVII. ACONITASE 1
}

\author{
BY WILLIAM ARTHUR JOHNSON \\ From the Department of Biochemistry, University of Sheffield
}

\author{
(Received 1 May 1939)
}

Since citric acid plays an important role in intermediary metabolism [Martius \& Knoop, 1936; 1937; Krebs \& Johnson, 1937] it was thought desirable to study in detail the reactions which citric acid may undergo in animal tissues. From the work of Martius \& Knoop [1937] it is known that citric acid in the presence of tissue extracts forms an equilibrium with cisaconitic acid and $l$-isocitric acid:

\section{(1) citric acid $\rightleftharpoons$ cisaconitic acid $\rightleftharpoons l$-isocitric acid}

The enzyme system bringing about the reversible hydration of cisaconitic acid has been shown to be different from fumarase and termed "aconitase" [Breusch, 1937]. This term will be used in this paper for the total enzyme system responsible for the reactions (1); it is left open whether one enzyme only brings about the two modes of reversible hydration of aconitic acid leading to citric acid or to $l$-iso-citric acid. The paper deals with some quantitative aspects of the reactions (1) especially with the investigation of the equilibrium between the three acids. After most of the work had been finished a paper of Martius appeared which partly covered the same ground [Martius, 1938]. The work reported in the present paper goes however beyond that of Martius in that it includes determinations of aconitic acid which Martius, lacking a suitable method, was unable to estimate.

\section{EXPERIMENTAL}

\section{Preparation of cisaconitic acid}

Anhydro-aconitic acid was prepared from ordinary (trans) aconitic acid by the method of Anschütz \& Bertram [1904]. Aconitic acid was boiled with acetyl chloride until a clear solution was obtained. The deep yellow solution was evaporated to dryness in vacuo over $\mathrm{NaOH}$, and the brown solid was crystallized several times from hot benzene. Eventually a white solid was obtained, which melted sharply at $76^{\circ}$.

The benzene was removed by standing in vacuo over paraffin oil, and the solid stored in a desiccator over $\mathrm{H}_{2} \mathrm{SO}_{4}$.

Cisaconitate solution was freshly prepared before use; a known amount of anhydro-aconitic acid was dissolved in ice-cold water and neutralized with $\mathrm{NaHCO}_{3}$.

\section{Quantitative determination of citric acid}

The method of Pucher et al. [1936] was used. Citric acid is oxidized in the presence of bromine to pentabromoacetone which is subsequently converted into a coloured material by means of $\mathrm{Na}_{2} \mathrm{~S}$, and is estimated colorimetrically. The use of dioxan as the colour stabilizer in place of pyridine was found to be much less objectionable, and did not affect the accuracy of the method. If the amount of citric acid to be determined exceeded $1 \mathrm{mg}$. the depth of colour was not strictly

1 Preliminary note in Chem. \& Ind. 58, 56 (1939). 
proportional. The solutions were therefore suitably diluted or else corrections were obtained from a calibration curve.

Cisaconitic acid did not give a colour when treated by this method.

\section{Quantitative determination of aconitic acid}

The method is based on the determination of the hydrogen required for the quantitative catalytic hydrogenation of the double bond. The catalyst used was a deposit of palladium on barium sulphate recommended by Köppen [1932], obtained from the Membranfilter G.m.b.h., Göttingen. The catalyst was suspended in water $\left(10 \mathrm{mg} . / \mathrm{ml}\right.$.) and a stream of $\mathrm{H}_{2}$ bubbled through. For the manometric determination the flasks were filled as follows:

$\begin{array}{lc}\text { Main compartment } & \text { Side bulb } \\ 2 \mathrm{ml} \text {. water } & - \\ 1 \mathrm{ml} .5 \% \mathrm{H}_{2} \mathrm{SO}_{4} \\ 0.5 \mathrm{ml} . \mathrm{Pd}_{\text {aspension }} & \\ \text { Do. } & \begin{array}{c}\text { ml. test solution } \\ \text { (acidified) }\end{array}\end{array}$

The manometers were filled with cylinder $\mathrm{H}_{2}$ washed with alkaline pyrogallol and acid dichromate. Rapid equilibration occurred at $40^{\circ}$, and in pure solution of aconitic acid the reaction was completed in 40 to $60 \mathrm{~min}$. (see Table I).

Table I. $\mathrm{H}_{2}$ uptake with pure aconitic acid solution in presence of palladium catalyst. Conditions as above

\begin{tabular}{lcrrrr}
\multicolumn{3}{c}{ Aconitic acid added $=172 \mu \mathrm{l}}$. & & & \\
Time from mixing (min.) & 15 & 30 & 50 & 70 & 290 \\
Extra hydrogen uptake over "blank" ( $\mu \mathrm{l})$. & 106 & 153.5 & 170 & 171 & 170
\end{tabular}

In applying this method to the determination of aconitic acid in biological media difficulty was encountered owing to the interference of proteins with the catalyst. The choice of protein precipitant is limited to substances which are not themselves reducible. The method finally adopted was as follows. The solution to be tested was deproteinized by the addition of $1 / 5$ th volume of $5 \% \mathrm{HPO}_{3}$ (freshly prepared). The precipitate was filtered off, and an aliquot part of the clear filtrate was strongly acidified with $\mathrm{H}_{2} \mathrm{SO}_{4}$. The aconitic acid was extracted $2 \mathrm{hr}$. with ether in a Kutscher-Steudel [1903] extractor. One ml. of water was added to the ethereal extract and the ether evaporated off. The residue was made up to a known volume with $5 \% \mathrm{H}_{2} \mathrm{SO}_{4}$, and the final solution tested as above.

The partition coefficient of cisaconitic acid between ether and water was found to be about 15:1 in favour of the aqueous phase at $20^{\circ}$. Under our conditions complete recovery was obtained with $2 \mathrm{hr}$. extraction.

\section{Recovery of aconitic acid added to extract of pigeon breast muscle (dilution 1 in 5)}

Mixtures were made up with varying amounts of aconitic acid as follows:

$10 \mathrm{ml}$. extract $+1 \mathrm{ml} .5 \% \mathrm{H}_{2} \mathrm{SO}_{4}+4 \mathrm{ml} .5 \% \mathrm{HPO}_{3}+$ aconitic acid.

The recovery of aconitic acid after treatment as above is given in Table II.

The reaction is general for a double bond and works equally well with cisand trans-aconitic acids, crotonic and fumaric acids. The latter can be estimated by re-extracting after hydrogenation and determining the succinic acid formed by the method of Szent-Györgyi as modified by Krebs [1937]. 
Table II. Recovery of aconitic acid from pigeon breast muscle extract

$\begin{array}{ccccc}\text { No. } & \begin{array}{c}\text { Aconitic acid } \\ \text { added }(\mu \mathrm{l} .)\end{array} & \mathrm{H}_{2} \text { uptake }(\mu \mathrm{l} .) & \begin{array}{c}\text { Aconitic acid } \\ \text { recovered }\end{array} & \text { \% recovery } \\ 1 & - & 116 & - & - \\ 2 & 1255 & 1320 & 1204 & 96 \\ 3 & 628 & 695 & 579 & 92 \\ 4 & 251 & 355 & 239 & 95\end{array}$

Hydroxy-acids do not react under these conditions, and ketonic acids react only slowly. As the addition of citrate to the dilute tissue extracts used does not give rise to the formation of ketonic acids under the conditions of our experiments, the method is sufficiently specific for our purpose.

\section{Metabolic quotients}

In most experiments the rates of reaction are expressed by the quotient

$$
\frac{\text { micromol. of substrate metabolized }}{\text { mg. tissue } \times \text { hours }} \text {. }
$$

In some experiments it seemed desirable to compare the rates of citric acid breakdown or formation with the rate of $\mathrm{O}_{2}$ uptake, since citric acid plays a role in the oxidative metabolism. The quantities of citric acid metabolized are therefore expressed in some tables in $\mu \mathrm{l} ., 1 \mathrm{~m}$.-mol. citric acid being considered equivalent to $22,400 \mu \mathrm{l}$. The rate of the metabolic reaction is expressed by the quotient

$$
\frac{\mu l \text {. substrate metabolized }}{\text { mg. dry tissue } \times \text { hours }} \text {. }
$$

\section{The reaction cisaconitic acid $\rightarrow$ citric acid}

Extraction of "aconitase". The majority of experiments were performed with extracts of pigeon breast muscle. Chilled breast muscle was minced through a Latapie mincer and ground with 5 vol. $0 \cdot 1 M$ phosphate buffer of $p H ~ 7.4$ (except where otherwise stated). Quartz (Merck's quartz sand "washed and calcined") was used to break up the tissue. The resulting suspension was rapidly centrifuged and the supernatant liquid used. This will be referred to as the "stock enzyme solution".

Aconitase is almost completely extracted by this method; a second or third extraction shows only traces of activity, as illustrated by the following experiment.

Table III. Extraction of aconitase from muscle tissue

$1 \mathrm{ml}$. stock enzyme, $2 \mathrm{ml}$. phosphate buffer $p \mathrm{H} \mathrm{7 \cdot 4,1} \mathrm{ml}$. cisaconitate $(0 \cdot 0081 \mathrm{M}) .40^{\circ}$.

Citric acid formed after 30 min. incubation

$\begin{array}{ll} & \mu \mathrm{mol} . \\ \text { First extract } & 6 \cdot 8 \\ \text { Second extract } & 0 \cdot 9 \\ \text { Third extract } & 0 \cdot 27 \\ \text { Fourth extract } & 0\end{array}$

The activity of the enzyme does not deteriorate within a fortnight if kept in the refrigerator.

The course of the citric acid formation from cisaconitic acid. To follow the rate of formation of citric acid from cisaconitic acid it was convenient to use dilute extracts, since the reaction is very rapid in the stock solution. Stock enzyme solution from pigeon breast muscle was diluted 50 times with $0 \cdot 1 M$ phosphate 
buffer $(p \mathrm{H} \mathrm{7 \cdot 4)}$. $3 \mathrm{ml}$. dilute extract were incubated with $1 \mathrm{ml}$. cisaconitate $(0.00735 M)$ at $40^{\circ}$ under anaerobic conditions, and the formation of citrate was measured at various intervals.

\section{Table IV}

$\begin{array}{lccccc}\text { Time of incubation (min.) } & 10 & 20 & 40 & 60 & 120 \\ \text { Citrate formed }(\mu \mathrm{mol} .) & 2 \cdot 2 & 4 \cdot 1 & 5 \cdot 6 & 6 \cdot 0 & 6 \cdot 4\end{array}$

The initial rate of citrate formation, expressed in the terms of a metabolic quotient, is thus: $\quad Q_{\text {citrate }}=120 \mu \mathrm{l} . / \mathrm{mg} . / \mathrm{hr}$.

The position of equilibrium cisaconitic acid $\rightleftharpoons$ citric acid in muscle extract. In the previous experiment the final amount of citrate represents $87 \%$ of the added cisaconitate. The following table shows that in other experiments in which the reaction was allowed to reach the equilibrium, the reaction generally stopped when $\mathbf{7 5 - 8 5 \%}$ of the added cisaconitate had been converted into citrate.

Table V. Stock enzyme solution diluted with $0 \cdot 1 \mathrm{M}$ phosphate buffer $\mathrm{pH} \% \cdot 4.40^{\circ} . \mathrm{N}_{2}$

\begin{tabular}{|c|c|c|c|c|c|}
\hline No. & $\begin{array}{l}\text { Dilution of } \\
\text { stock enzyme } \\
\text { solution }\end{array}$ & $\begin{array}{l}\text { Time of } \\
\text { incubation } \\
\text { min. }\end{array}$ & $\begin{array}{l}\text { Cisaconitate } \\
\text { added } \\
\mu \mathrm{mol} .\end{array}$ & $\begin{array}{c}\text { Citrate } \\
\text { formed } \\
\mu \mathrm{mol} .\end{array}$ & $\stackrel{\%}{\%}$ conversion \\
\hline $\begin{array}{l}1 \\
2 \\
3 \\
4 \\
5\end{array}$ & $\begin{array}{r}3 \\
9 \\
40 \\
10 \\
2\end{array}$ & $\begin{array}{r}130 \\
60 \\
60 \\
120 \\
120\end{array}$ & $\begin{array}{c}7 \cdot 9 \\
7 \cdot 0 \\
6 \cdot 35 \\
755 \\
685\end{array}$ & $\begin{array}{c}6 \cdot 75 \\
5 \cdot 2 \\
5 \cdot 35 \\
583 \\
535\end{array}$ & $\begin{array}{l}85 \\
75 \\
85 \\
78 \\
78\end{array}$ \\
\hline
\end{tabular}

The $\mathrm{pH}$ optimum of aconitase in muscle extract. The experiments were arranged in such a way as to allow the determination of the initial rates of citric acid formation from cisaconitic acid by extracts of different $p H$. The curve shows a sharp maximum at $p H \mathbf{7 \cdot 4}$. It will later be seen that the (apparent) optimum in tissue slices is at $\mathbf{7 \cdot 9}$.

\section{Table VI. pH optimum}

$3 \mathrm{ml}$. enzyme (stock enzyme diluted 60 times with buffer of appropriate $p \mathrm{H})+1 \mathrm{ml}$. cisaconitate $(0.01 \mathrm{M}) .20 \mathrm{~min}$. at $40^{\circ}$

$\begin{array}{lllllllll}p \mathrm{H} & \mathbf{2 \cdot 6} & \mathbf{3 . 9} & 4 \cdot 9 & \mathbf{6 \cdot 2} & \mathbf{6 \cdot 8} & \mathbf{7 \cdot 4} & \mathbf{8 \cdot 6} & \mathbf{9 \cdot 2} \\ \text { Citrate formed ( } \mu \text { mol. }) & 0 \cdot 27 & 0.2 & 0 \cdot 7 & 1 \cdot 2 & 4 \cdot 1 & 5 \cdot 0 & 2 \cdot 8 & 1.5\end{array}$

Activity of other tissues. Intact cells. Aconitase occurs in all the animal tissues which we examined, with the exception of red blood cells. The rate of formation of citric acid from cisaconitic acid in various tissues is given in the following table:

Table VII. Citric acid formation from cisaconitic acid by rat tissues

Bicarbonate saline. $5 \% \mathrm{CO}_{2}$ in $\mathrm{N}_{2}$. $40^{\circ}$. Initial concentration of cis-aconitate $=0.025 \mathrm{M}$.

$\begin{array}{ccc}\text { Tissue } & \begin{array}{c}\text { Time of } \\ \text { shaking min. }\end{array} & \begin{array}{c}Q_{\text {citrate }} \\ \mu \mathrm{l} . / \mathrm{mg} . / \mathrm{hr} .\end{array} \\ \text { Liver } & 30 & 8 \cdot 0 \\ \text { (sliced) } & 60 & 8 \cdot 5 \\ \text { Kidney cortex } & 30 & 12 \cdot 5 \\ \text { (sliced) } & 60 & 14 \cdot 0 \\ \text { Testis } & 30 & 4 \cdot 2 \\ \text { (teased) } & 60 & 5 \cdot 0 \\ \text { Brain cortex (sliced) } & 60 & 4 \cdot 6\end{array}$


The rate increases on raising the initial concentration of cisaconitic acid (Table VIII).

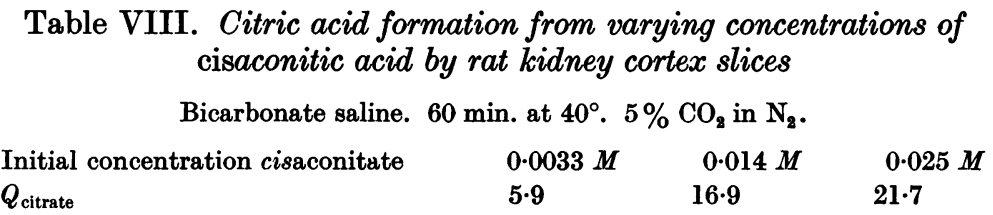

Tissue extracts. Extracts of rat tissues were made in the same way as described for pigeon breast muscle, except that the preliminary mincing was omitted. In extracts the rate of reaction was always much higher than in slices.

\section{Table IX. Citric acid formation from cisaconitic acid by rat tissue extracts}

Phosphate buffer $p H 7 \cdot 4 . \mathrm{N}_{2} .60$ min. at $40^{\circ}$. Initial concentration cisaconitate $=0.025 M$.

$\begin{array}{lc}\text { Tissue extracted } & Q_{\text {citrate }} \\ \mu \mathrm{l} . / \mathrm{mg} . / \mathrm{hr}\end{array}$

The slower rate of reaction observed in slices may be due to the fact that the $p \mathrm{H}$ in the tissue is not optimal for the reaction. It has been shown that aconitase in pigeon breast muscle extract shows a sharp $p H$ maximum at $7 \cdot 4$. The following experiment shows that the $p H$ optimum is different in slices (about $p H$ 8.0).

Table X. Formation of citric acid from cisaconitic acid by rat liver slices in bicarbonate medium of varying $\mathrm{pH}$

Bicarbonate saline. $\mathrm{CO}_{2}$ in $\mathrm{N}_{2} .30 \mathrm{~min}$. at $40^{\circ}$. Initial concentration cisaconitate $=0.067 \mathrm{M}$.

$\begin{array}{lrrrr}p \mathrm{H} & \mathbf{8 \cdot 3} & \mathbf{8 \cdot 0} & \mathbf{7 \cdot 8} & \mathbf{7 \cdot 6 5} \\ Q_{\text {citrate }} & \mathbf{5 4 \cdot 2} & \mathbf{7 5 \cdot 5} & \mathbf{7 1 \cdot 0} & \mathbf{5 5 \cdot 0}\end{array}$

It is probable that this difference is an apparent one. The concentration of bicarbonate in the tissue is known to be lower than in the medium, whilst the concentrations of free $\mathrm{CO}_{2}$ are of the same order in medium and tissue. The $p \mathrm{H}$ of the tissue is thus lower than that of the medium. The experiment recorded in Table $\mathrm{X}$ does not therefore represent the real $p \mathrm{H}$ activity curve of aconitase. The latter can only be measured in extracts.

\section{The reaction citric acid $\rightarrow$ cisaconitic acid}

To measure the formation of cisaconitic acid from citric acid, pigeon breast muscle extract was incubated anaerobically at $40^{\circ}$ with citric acid, and the resulting solution tested for the formation of aconitic acid. A small but definite quantity of aconitic acid, amounting finally to $4-5 \%$ of the added citric acid, was found; this value did not further increase on prolonged incubation. 
Table XI. Course of aconitic acid formation from citric acid

Stock enzyme solution (diluted 12 times) in phosphate buffer $p \mathrm{H} \mathrm{7.4.0.02M}$ citrate. $40^{\circ}$.

Time of shaking (min.)

Aconitate formed ( $\mu \mathrm{mol}$.)

\section{5}

$2 \cdot 8$
10

$4 \cdot 0$

\section{0}

$4 \cdot 8$
40

$5 \cdot 9$

Citric acid added $=146 \mu \mathrm{mol}$.

The effect of the citric acid concentration on the formation of aconitic acid is shown in the following table:

Table XII. Formation of aconitic acid from citric acid (final values; effect of citrate concentration)

Pigeon breast muscle extract. $p \mathrm{H} \mathrm{7 \cdot 4.} 40^{\circ}$.

Citrate added
$\boldsymbol{\mu}$ mol.
145
5020
2480
3380
4055
1000

Aconitate formed
$\mu \mathrm{mol}$.
$5 \cdot 9$
$240 \cdot 0$
$127 \cdot 0$
$150 \cdot 0$
$193 \cdot 0$
$42 \cdot 0$

$\%$ conversion
$4 \cdot 1$
$4 \cdot 8$
$5 \cdot 1$
$4 \cdot 4$
$4 \cdot 75$
$4 \cdot 2$

\section{Formation of isocitric acid}

The following tables give the results of experiments in which the sum of the citric acid and aconitic acid remaining after incubation was compared with the amount of substrate added.

Table XIII. Citric acid formed and aconitic acid remaining after incubation of pigeon breast muscle extract with cisaconitic acid

\begin{tabular}{|c|c|c|c|c|c|}
\hline $\begin{array}{c}\text { Aconitate } \\
\text { added } \\
\mu \mathrm{mol} .\end{array}$ & $\begin{array}{l}\text { Time of } \\
\text { incubation } \\
\text { min. }\end{array}$ & $\begin{array}{c}\text { Citrate } \\
\text { formed } \\
\boldsymbol{\mu} \mathrm{mol} .\end{array}$ & $\begin{array}{c}\begin{array}{c}\text { Aconitate } \\
\text { left } \\
\mu \mathrm{mol} .\end{array} \\
\text {. }\end{array}$ & Loss & $\%$ loss \\
\hline $\begin{array}{r}754 \\
754 \\
\mathbf{7 5 4} \\
685 \\
1020\end{array}$ & $\begin{array}{r}5 \\
30 \\
120 \\
120 \\
90\end{array}$ & $\begin{array}{r}87 \\
450 \\
582 \\
536 \\
615\end{array}$ & $\begin{array}{r}486 \\
104 \\
65 \\
60 \\
285\end{array}$ & $\begin{array}{r}181 \\
100 \\
107 \\
89 \\
140\end{array}$ & $\begin{array}{l}24 \\
13 \\
14 \\
13 \\
14\end{array}$ \\
\hline
\end{tabular}

Table XIV. Aconitic acid formed and citric acid left, after incubation of pigeon breast muscle extract with citric acid

$\begin{array}{lrcccc}\begin{array}{c}\text { Citrate } \\ \text { added }\end{array} & \begin{array}{c}\text { Time of } \\ \text { incubation } \\ \mu \text { mol. }\end{array} & \begin{array}{c}\text { Aconitate } \\ \text { formed } \\ \mu \text { mol. }\end{array} & \begin{array}{c}\text { Citrate left } \\ \mu \text { mol. }\end{array} & \text { Loss } & \% \text { loss } \\ 2480 & 30 & 108 & 1680 & 692 & 28 \\ 2480 & 120 & 127 & 1790 & 563 & 22 \\ 3380 & 330 & 150 & 2780 & 450 & 13 \\ 4050 & 1320 & 193 & 3150 & 707 & 17 \\ 1000 & 90 & 46 & 830 & 124 & 12\end{array}$

In all experiments, the measured sum of citric and aconitic acid equivalents is less than the amount of substrate added. This indicates the formation of a third substance. From schemes put forward previously [Martius, 1937] the missing fraction was expected to be isocitric acid, and experiments were performed in which the development of optical rotation in the extracts after incubation with either citric or cisaconitic acids was measured. These experiments will not be reported in detail since they do not go beyond Martius's results [1938]. 
In accordance with Martius the rotation observed corresponded to $10-20 \%$ isocitric acid, in agreement with the view that the above mentioned deficit is due to the formation of isocitric acid. Our experiments also confirm Martius's finding of a rapid formation of isocitric acid from cisaconitic acid, followed by a partial disappearance (see curve 2 of Martius's paper).

\section{Aconitase in cucumber seeds}

Aconitase also occurs in cucumber seeds [Martius, 1938] and it seemed of interest to compare the enzymes from different sources. An extract of dried cucumber seeds was prepared according to the directions of Scherstén [1936]. One part of ground seed kernel was extracted with two parts $0.87 \% \mathrm{~K}_{2} \mathrm{HPO}_{4}$ and the centrifuged extract used.

(a) Incubation with cisaconitic acid. The amount of citric acid formed by incubation of this extract with cisaconitic acid, together with the amount of aconitic acid remaining in the solution, was measured. Table XV summarizes the results of three experiments.

Table XV. Cucumber seed extract incubated with cisaconitate $40^{\circ}$. Octyl alcohol added

Initial concentration of aconitic acid $=0.03 M$ approx.

$\begin{array}{ccccccc}\text { Vol. of } & \begin{array}{c}\text { Aconitate } \\ \text { anzyme }\end{array} & \begin{array}{c}\text { Added } \\ \text { No. }\end{array} & \begin{array}{c}\text { Citrate formed } \\ \mu \text { mol. }\end{array} & \begin{array}{c}\text { Aconitate } \\ \text { left } \\ \mu \text { mol. }\end{array} & \begin{array}{c}\text { Loss } \\ \text { incubation } \\ \text { min. }\end{array} \\ 1 & 15 & 500 & 237(47 \%) & 74 \cdot 5 & 191(38 \%) & 120 \\ 2 & 15 & 607 & 58(9 \%) & 290 & 259(42 \%) & 20 \\ & 1 & 607 & 121(20 \%) & 250 & 235(39 \%) & 40 \\ & & 607 & 168(27 \%) & 220 & 218(36 \%) & 60 \\ & & 607 & 231(27 \%) & 177 & 198(32 \%) & 120 \\ 3 & 15 & 607 & 295(48 \%) & 99 & 214(35 \%) & 240 \\ & & 540 & 87(16 \%) & 300 & 155(29 \%) & 30\end{array}$

(b) Incubation with citric acid. In another series of experiments cucumber seed extract was incubated with citric acid, and the amount of aconitic acid formed, together with the amount of citric acid remaining, was determined (Table XVI).

Table XVI. Cucumber seed extract incubated with citrate at $40^{\circ}$. Octyl alcohol added

Initial concentration of citrate $=M / 30$. Amounts of metabolites given in $\mu$ mol.

\begin{tabular}{|c|c|c|c|c|c|c|}
\hline No. & $\begin{array}{c}\text { Vol. of } \\
\text { enzyme } \\
\text { ml. }\end{array}$ & $\begin{array}{l}\text { Citrate } \\
\text { added }\end{array}$ & $\begin{array}{l}\text { Aconitate } \\
\text { formed }\end{array}$ & $\begin{array}{c}\text { Citrate } \\
\text { left }\end{array}$ & Loss & $\begin{array}{l}\text { Time of } \\
\text { incubation } \\
\text { min. }\end{array}$ \\
\hline 1 & 15 & 500 & $21(4 \cdot 2 \%)$ & 466 & $13(2.6 \%)$ & 30 \\
\hline 2 & 15 & 500 & $23(4.6 \%)$ & 428 & $49(5 \cdot 8 \%)$ & 60 \\
\hline 3 & 15 & 500 & $22(4.4 \%)$ & 500 & _ & 120 \\
\hline 4 & 15 & 500 & $29(5.8 \%)$ & 476 & - & 240 \\
\hline 5 & 15 & 500 & $27(5.4 \%)$ & 466 & $9(1.8 \%)$ & 360 \\
\hline
\end{tabular}

From these figures it is seen that the activity of the enzyme in cucumber seed is very much lower than in muscle (compare Table IV and Tables XV and XVI). The initial velocity of the reaction in cucumber seed extract is about $1.6 \%$ of that in muscle extract. Both reactions, cisaconitic acid $\rightarrow$ citric acid and citric acid $\rightarrow$ cisaconitic acid take place in cucumber seed extract, but no true equilibrium was reached in our experiments. 
There is a small deficit when citric acid is the substrate $(2-6 \%)$ but a very considerable loss when cisaconitic acid is the substrate $(32-42 \%)$. The fact that no equilibrium is established may be due to the comparatively low activity of the enzyme.

\section{Discussion}

Aconitase is an unusual enzymic system in that it forms two different isomeric compounds through addition of water to a double bond. No analogy is known to occur amongst enzymes, but many similar reactions are known to the organic chemist. For example, the addition of iodine monochloride to propylene gives $\mathrm{CH}_{3} \mathrm{CHCl} . \mathrm{CH}_{2} \mathrm{I}(69 \%)$ and $\mathrm{CH}_{3} \mathrm{CHI} . \mathrm{CH}_{2} \mathrm{Cl}(31 \%)$ [Ingold \& Smith, 1931]. These reactions, however, are not reversible.

\section{SUMMARY}

1. A method has been worked out for the quantitative determination of aconitic acid based on the catalytic hydrogenation of the double bond.

2. The action of aconitase (the conversion of citric acid into cisaconitic acid and the reverse reaction) has been studied in animal tissues. Aconitase is extracted with $M / 10$ phosphate buffer $p \mathrm{H} 7 \cdot 4$ from minced pigeon breast muscle and other tissues.

3. In tissue extracts aconitase converts about $75-85 \%$ of added cisaconitic acid into citric acid.

4. Citric acid incubated with pigeon breast muscle extract forms about $4 \%$ aconitic acid.

5. The equilibrium is reached when the solution contains about $16 \%$ isocitric acid (Martius), about $4 \%$ cisaconitic acid and about $80 \%$ citric acid.

6. The $p \mathrm{H}$ optimum of aconitase in tissue extracts is at $7 \cdot 4$. In tissue slices the (apparent) optimum is $\mathbf{7 \cdot 9}$.

7. Aconitase was found in pigeon breast muscle, rat liver, kidney cortex, testis, brain cortex, lung, submaxillary gland, intestine, but not in red blood cells of the rat.

8. Aconitase also occurs in cucumber seeds but its activity is only $1 \cdot 6 \%$ of that of pigeon breast muscle and no true equilibrium between cisaconitic, isocitric and citric acids was reached with cucumber seed extract.

I should like to express my appreciation to Dr H. A. Krebs, for suggestions and help, and also to the Medical Research Council for a maintenance grant.

\section{REFERENCES}

Anschütz \& Bertram (1904). Ber. dtsch. chem. Ges. 37, 3967.

Breusch (1937). Hoppe-Seyl. Z. 250, 262.

Ingold \& Smith (1931). J. chem. Soc. pp. 2742, 2752.

Köppen (1932). Z. Elektrochem. 38, 938.

Krebs (1937). Biochem. J. 31, 2095.

—_ Johnson (1937). Enzymologia, 4, 148, 1937.

Kutscher \& Steudel (1903). Hoppe-Seyl. Z. 39, 474.

Martius (1937). Hoppe-Seyl. Z. 247, 104.

- (1938). Hoppe-Seyl. Z. 257, 29.

— \& Knoop (1936). Hoppe-Seyl. Z. 242, 1.

- (1937). Hoppe-Seyl. Z. 246, 1.

Pucher, Sherman \& Vickery (1936). J. biol. Chem. 113, 235.

Scherstén (1936). Skand. Arch. Physiol. 74, Supplemen 7. 